\title{
Evaluation of technical efficiency of rice farmers in canal and tank irrigated systems in Tamil Nadu
}

\author{
R. VASANTHI AND M. CHANDRASEKARAN
}

\begin{abstract}
The present study undertaken in Cauvery delta zone and Southern zone in the state of Tamil Nadu has estimated the resource use efficiency in rice production and has assessed the effect of farm specific socio economic factors affecting the technical efficiency. A stochastic frontier production function was estimated to determine technical efficiency of individual farms. The data were collected for two years from the Cost of Cultivation Scheme of Tamil Nadu Centre. The results of Cobb-Douglas stochastic production function indicated that the estimated parameters for seed (positive), labour hours(negative) and value of pesticides (negative) are significant and hence, playing a major role in influencing rice production under canal irrigation. But in the case of tank irrigation system the estimated parameters for fertilizers, labour hours, machine hours are significantly and positively influenced the yield of paddy. Moreover the marginal value product to input price ratios for the variables influencing significantly revealed that it will be profitable to increase the use of seeds in canal irrigation and fertilizer and human labour in tank irrigation system. The $\mathrm{Z}$ test results indicated that there is a significant difference between the average technical efficiency estimates between canal and tank irrigation systems.
\end{abstract}

KEY WORDS : Rice, Canal and Tank irrigation, Technical efficiency, Cobb-Douglass production function, Stochastic frontier

How to cite this paper : Vasanthi, R. and Chandrasekaran, M. (2014). Evaluation of technical efficiency of rice farmers in canal and tank irrigated systems in Tamil Nadu. Internat. J. Com. \& Bus. Manage., 7(2) : 343-348. 